\title{
皮膜処理による給水加熱器伝熱管からの金属溶出抑制
}

\author{
竹田 貴代子 ${ }^{\mathrm{a}}$ ，穴田 博之 ${ }^{\mathrm{b}}$, 中井 俊之 ${ }^{\mathrm{b}}$ \\ a 住友金属工業株) 総合技術研究所 ( ⿳ 660-0891 兵庫県尼崎市扶桑町 1-8) \\ b 住友金属工業(株) 特殊管事業所 ( $=660-0856$ 兵庫県尼崎市東向島西之町 1)
}

\section{Metal Release Reduction from TP304L for the Feed Water Heater Tube by Pre-Filming}

\author{
Kiyoko TAKEDA ${ }^{\text {a }}$, Hiroyuki ANADA ${ }^{\text {b }}$ and Toshiyuki NAKAI ${ }^{b}$
}

${ }^{a}$ Corporate R\&D Laboratories, Sumitomo Metal Industries, Ltd.(1-8, Fuso-cho, Amagasaki-shi, Hyogo 660-0891)

${ }^{\mathrm{b}}$ Steel Tube Works, Sumitomo Metal Industries, Ltd.(1, Nishino-cho, Higashi-mukojima, Amagasaki-shi, Hyogo 660-0856)

Keywords : Pre-Filming, Radiological Protection, Metal Release, Feed Water Heater Tube, High Temperature Oxidation

\section{1.はじめに}

軽水炉の冷却水は, 燃料被覆管を冷却するとともに, 中性 子の減速材, 燃料で発生する熱エネルギーを次過程に伝達す る働きをする。この冷却材の水質は水化学と呼ばれることが あるが, 水化学は構造材や燃料の健全性確保, また定期点検 などの作業従事者の放射線被ばくの低減などの観点から管理 されている ${ }^{1)}$ 。国内の放射線作業従事者の被ばく線量は, 初 期のプラントと比べ種々の対策により低減されてきたが，さ らなる低減が要望されている ${ }^{2)}$ 。放射線被ばくの主要因とし て, 放射性腐食生成物が挙げられる。炬内の炭素鋼やステン レス鋼などの構造材が冷却水と腐食反応すると, 構造材表面 から金属が溶出する。溶出した金属は, 酸化物, 水和物, イ オンなど複雑な化学形態の腐食生成物となる。これら腐食生 成物が燃料被覆管の外面に付着すると, 中性子照射を受けて 放射化する。例えば, 半減期の長いものとして $\mathrm{Fe} \rightarrow{ }^{59} \mathrm{Fe}$ (半 減期: 45.1 日), $\mathrm{Ni} \rightarrow{ }^{58} \mathrm{Co}$ (同:71.3日), $\mathrm{Co} \rightarrow{ }^{60} \mathrm{Co}$ (同:5.272 年)などがある。沸騰水型軽水炉 (BWR)の代表的な腐食生成 物には $\mathrm{NiFe}_{2} \mathrm{O}_{4}, \alpha-\mathrm{Fe}_{2} \mathrm{O}_{3}, \mathrm{NiO}$ などが挙げられ ${ }^{3)}$ ，これら腐 食生成物は, ${ }^{59} \mathrm{Fe},{ }^{60} \mathrm{Co},{ }^{58} \mathrm{Co}$ などの放射性同位体が含まれる ${ }^{4)}$ 。 これに対し, 実際の運用において放射線量を低減するため, 耐食性の良い材料や低 Co 材の採用, 冷却材の水化学制御が 行われている ${ }^{1)}$ 。例えば, 水化学制御の 1 つとして Zn 注入 が挙(゙られる ${ }^{5)}$ ）。これは冷却水に $10 \sim 15 \mathrm{ppb}$ 程度の $\mathrm{Zn}$ を注入して, 腐食生成物からなる酸化膜を緻密にすることに より，酸化膜中へ取り込まれる ${ }^{60} \mathrm{Co}$ を抑制する技術である。 また, 軽水炉の定期点検作業時の放射線量を低減するため, 配管に付着した腐食生成物を化学的に除去することがある。 しかし，この後の稼働中に，金属表面は腐食環境と直接接す ることになり, 金属溶出が増加することがあるため, 再稼働 前に水質を制御して $\mathrm{Fe}_{3} \mathrm{O}_{4}$ 酸化膜を形成させ金属溶出を抑制 する技術も開発されている ${ }^{8)} 。 \mathrm{Fe}_{3} \mathrm{O}_{4}$ 酸化膜は金属溶出を抑制 するだけでなく, ${ }^{60} \mathrm{Co}$ の取込も抑制すると報告されている ${ }^{9), 10)}$ 。
表 1 極低 Co-SUS304L の化学成分例 (mass \%)

\begin{tabular}{c|c|c|c|c|c|c}
\hline $\mathrm{C}$ & $\mathrm{Si}$ & $\mathrm{Mn}$ & $\mathrm{Cr}$ & $\mathrm{Ni}$ & $\mathrm{Co}$ & $\mathrm{Fe}$ \\
\hline 0.018 & 0.39 & 1.2 & 18.3 & 8.4 & 0.019 & 残部 \\
\hline
\end{tabular}

一方, 近年, 新設の BWR プラントでは, 運転開始初期に 冷却水中の $\mathrm{Cr}$ 濃度が上昇することが課題の 1 つとされてい る ${ }^{11)}$ 。冷却水中の $\mathrm{Cr}$ 濃度が高くなると, $\mathrm{pH}$ が低下し, 燃 料被覆管表面に付着した放射性同位体を含む腐食生成物の溶 解を促す。これが冷却水中の放射線量の上昇に影響を与える と考えられている。そのため, 初期の冷却水中 $\mathrm{Cr}$ 濃度の抑 制が望まれる。 $\mathrm{Cr}$ 濃度上昇は, 冷却給水を運ぶ給水加熱器 伝熱管からの溶出 $\mathrm{Cr}$ が主とされている。そこで, 給水加熱 器伝熱管からの Cr 溶出を抑制するため, 管の内面に皮膜処 理を施す技術を開発した。前述のように, 皮膜処理は軽水炉 の起動もしくは停止の期間に冷却水を化学的に制御して行わ れるが, 本報では, 通常に給水加熱器伝熱管を製造する過程 での高温酸化の適用と皮膜処理管の $\mathrm{Cr}$ 溶出挙動について述 べる ${ }^{12)}$ 。

\section{2. 給水加熱器伝熱管}

給水加熱器伝熱管 (概寸 : 外径 $16 \mathrm{~mm}$, 肉厚 $1 \mathrm{~mm}$, 長さ 約 $20 \mathrm{~m}$ ) にはSUS304L 製が使用されている。表 1 に代表的 な化学成分を示す。前述のように, 溶出 Co が放射化した ${ }^{60} \mathrm{Co}$ は半減期が 5.272 年と長い。そのため, 炉内構造に用い られるステンレス鋼の不純物 Co 量は通常 0.2 mass \% 程度に 規制されているが, 放射線量の低減に寄与する重要部材に対

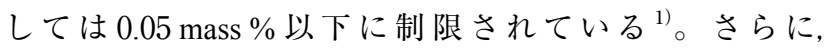
SUS304L の素材をスクラップなどを原料とする電気炉でな く, 鉄鉱石などを原料として不純物を制御することに適する 高炉で溶製することにより，さらなる $0.019 \%$ の極低 Co を 実用化している。 


\section{3. 皮膜処理}

酸化皮膜には，管内面からの金属溶出を抑制するためのバ リアとしての働きが必要である。そのためには, 使用環境で ある高温水中での安定性が必要である。BWR プラントの冷 却水水質管理例として, $\mathrm{pH}=5.6 \sim 8.6$ が示されている ${ }^{13)}$ 。 図 1 の電位 $-\mathrm{pH}$ 図に示すように, 給水加熱器伝熱管の使用 温度に近い $250{ }^{\circ} \mathrm{C}$ の中性域では, $\mathrm{Cr}$ 酸化物が安定であるこ とが知られていることから ${ }^{14)}, \mathrm{Cr}$ 酸化皮膜が管内面からの 金属イオン溶出に対するバリアとして有効であると考えた。 また，SUS304L は主として Cr， Ni， Fe からなる。図 2 に金 属酸化物の生成エネルギーを示すが ${ }^{15)}$, 酸素ポテンシャル は $\mathrm{Cr}, \mathrm{Fe}, \mathrm{Ni}$ の順で低いことから, $\mathrm{Cr}$ が酸素との親和力が 強く酸化されやすいことが分かる。そこで, 熱処理中の酸素 ポテンシャルを制御することにより，選択的に $\mathrm{Cr}$ のみを酸

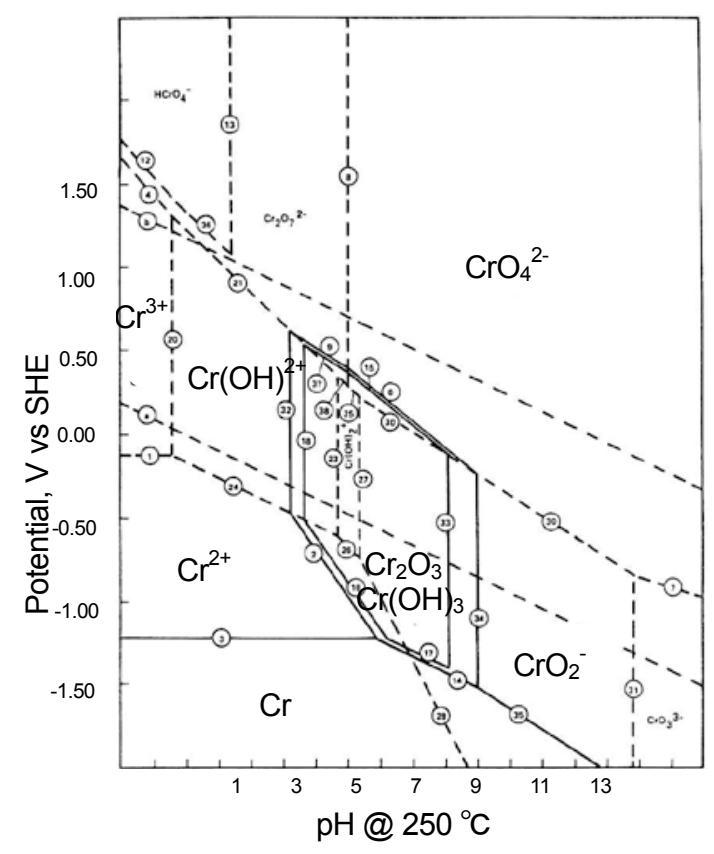

図 1 電位 $-\mathrm{pH}$ 図 ${ }^{14)}$

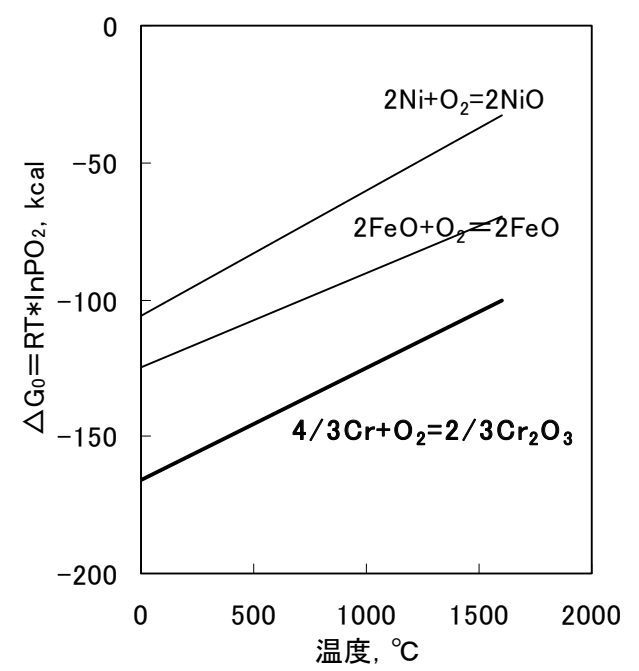

図 2 金属酸化物の生成エネルギー図 ${ }^{15)}$
化することを考えた。実際には, 管製造の最終の熱処理 $(1000$ 〜 $1100{ }^{\circ} \mathrm{C}$ 程度)において, 管の外面は通常の $100 \%$ 水素ガス, 管の内面に酸素ポテンシャルを制御した水素ガスを通気する こととした。酸素ポテンシャルは, 水素ガスに含まれる微量 水分の露点により制御した。

皮膜処理後の管内面外観写真を図 3 に示す。露点が高くな る, すなわち水素ガス中の酸素ポテンシャルが高くなると, 酸化皮膜が厚くなり色が濃くなっている。図 4 の酸化皮膜厚 さと露点の相関からも, 露点が高くなると酸化皮膜が厚くな ることが定量的に示される。図 5 にX線光電子分光法 (ESCA)による深さ方向組成分析の一例を示す。酸素プロ ファイルがピークの半分以上の領域を酸化皮膜厚さとすると, 露点 - $20{ }^{\circ} \mathrm{C}$ の場合, 酸化皮膜厚さは約 $75 \mathrm{~nm}$ であった。酸

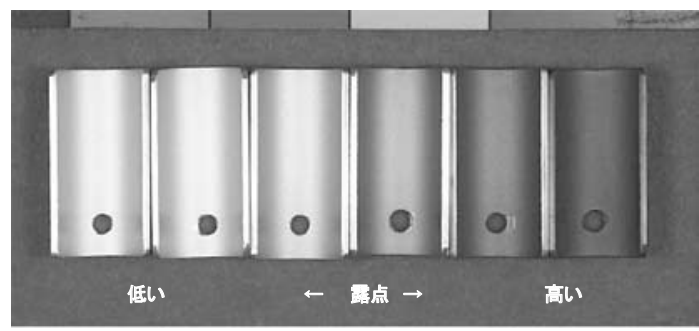

図 3 皮膜処理後の管内面外観写真

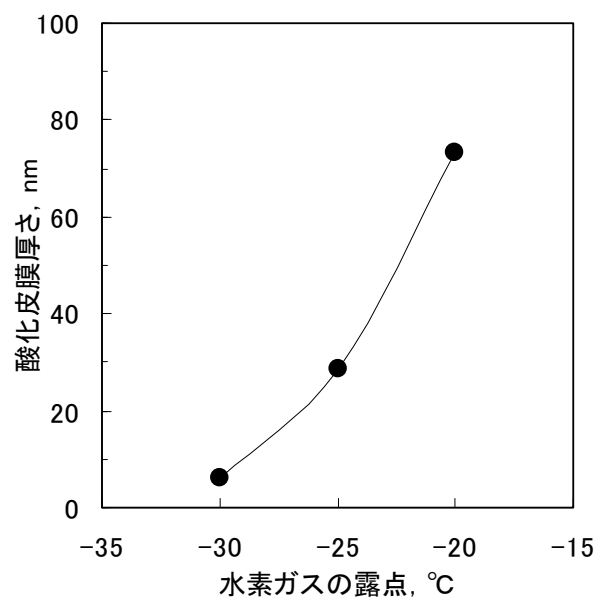

図 4 酸化皮膜厚さと露点の相関

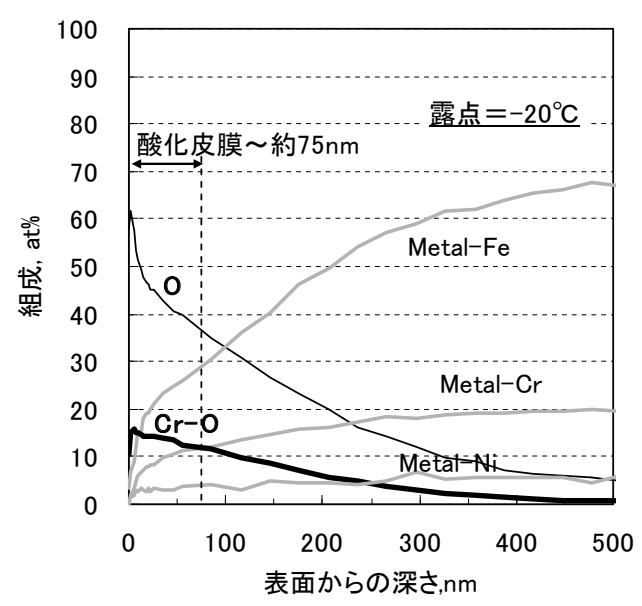

図 5 酸化皮膜の深さ方向組成分析結果の一例 


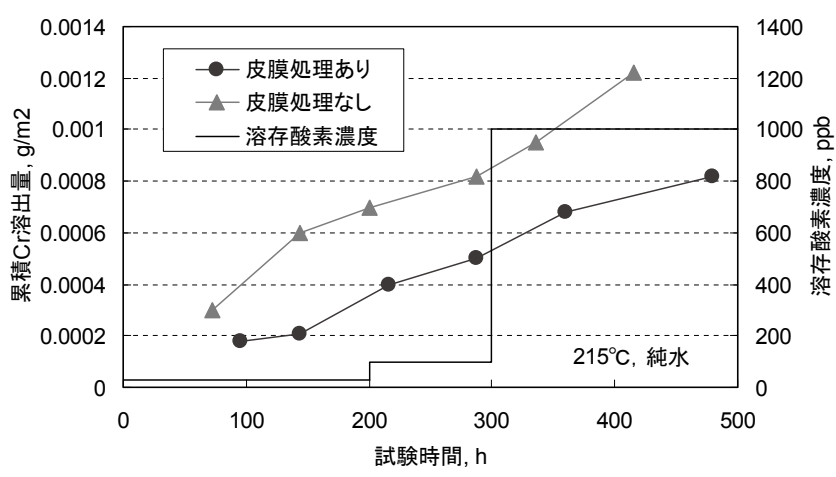

図 $6 \mathrm{Cr}$ 溶出特性に及ぼす $\mathrm{Cr}$ 酸化皮膜および溶存酸素濃度 $(\mathrm{pH})$ の 影響

化皮膜は，表面から $10 \mathrm{~nm}$ までが $\mathrm{Cr}$ 酸化物主体で，その内 層は $\mathrm{Cr}$ 酸化物と金属 $\mathrm{Fe}, \mathrm{Cr}, \mathrm{Ni}$ が混在している領域であった。 酸化皮膜と母材の界面近傍に, 耐食性の観点から懸念される $\mathrm{Cr}$ 欠乏層は認められなかった。一方, 露点が高くなり $\mathrm{Fe} も$ 酸化される酸素ポテンシャルに達すると, 表面の酸化皮膜に は $\mathrm{Cr}$ 酸化物のみならず Fe 酸化物も混在するようになるため, 適切な露点制御が $\mathrm{Cr}$ 酸化皮膜形成の重要なポイントとなる。 また，管内面を通気するガス量と熱処理温度，時間を制御す ることにより, 酸化皮膜は長さ約 $20 \mathrm{~m}$ の管の長手方向に均一 に，工業的な量産工程で生成させることが可能になっている。

\section{4. 溶出特性}

$\mathrm{Cr}$ 酸化皮膜が給水加熱器伝熱管の $\mathrm{Cr}$ 溶出特性に及ぼす影 響を図 6 に示す。給水加熱器伝熱管の使用環境を模擬した $215{ }^{\circ} \mathrm{C}, 2.2 \mathrm{MPa}$ の高温高圧純水中で $\mathrm{Cr}$ 溶出量を評価した結 果で, 縦軸の累積 $\mathrm{Cr}$ 溶出量は $\mathrm{Cr}$ イオン, 金属 $\mathrm{Cr}, \mathrm{Cr}$ 酸化 物の累計の推移を示している。試験時間 $0 \sim 200 \mathrm{~h}$ は溶存酸 素濃度が $30 \mathrm{ppb}$ で, これは実際の給水の溶存酸素濃度の下 限に近く，また $200 〜 300 \mathrm{~h}$ は $100 \mathrm{ppb}$ と上限に近い ${ }^{1)}$ 。0 $\sim 300 \mathrm{~h}$ の変化から, 通常の給水加熱器伝熱管の使用が想定 される環境において，Cr 酸化皮膜を有する給水加熱器伝熱 管内面からの $\mathrm{Cr}$ 溶出量は, 皮膜処理を施していない給水加 熱器伝熱管の約 $1 / 2$ に低減されていることが分かる。Cr 酸化 皮膜は $\mathrm{pH}$ が低下すると不安定になることが知られているた め, $300 \sim 500 \mathrm{~h}$ は溶存酸素濃度 $1000 \mathrm{ppb}$ と実環境より上昇 させると, 皮膜処理していない管の総溶出量は増加したが, 皮膜処理した管は飽和の傾向が認められた。皮膜処理を施し ていない管の内表面にも，0～ $300 \mathrm{~h}$ の間に腐食生成物から なる酸化膜が形成されていたと考えられるが，水溶液中で形 成された薄い水和物であるため, $\mathrm{pH}$ が上昇すると溶解した ため, $\mathrm{Cr}$ 溶出量が増加したと推察される。一方, 皮膜処理 で形成した $\mathrm{Cr}$ 酸化皮膜は, 熱処理という高温酸化で形成さ れた適度な厚さを有する緻密な酸化物であるため, $\mathrm{pH}$ が上 昇しても安定であると考えられた。

\section{5.おわりに}

1970 年に日本で最初の商用発電が始まって以来 40 年以上, 原子力材料は製造技術確立，安全性確保から信頼性向上，性 能向上と研究開発が変遷してきた。ここで紹介した皮膜処理 技術は，安全性の 1 つである放射線量低減に対し，従来使用 されている配管の性能向上という観点から，工業的にアプ ローチした成果である。また，実際に国内の新設 BWR に水 化学制御とも併せて適用され, 課題となる初期の放射線量が 極めて低かったことも報告されている ${ }^{11)} 。 さ ら に ，$ 本技術 は軽水炉の他構造部位にも適用可能であり, 新たな展開を検 討中である。

- 極低 Co-SUS304L 給水加熱器伝熱管の最終熱処理工条件を 制御することにより, 鋼中の $\mathrm{Cr}$ を選択酸化し, 約 $20 \mathrm{~m}$ 長 さの管内面に Cr 酸化皮膜を均一に形成することが工業的 に可能である。

-高温酸化で形成した $\mathrm{Cr}$ 酸化皮膜は BWR 模擬環境でも安 定で, $\mathrm{Cr}$ 溶出は皮膜処理を施していない管の約 $1 / 2$ に低減 でき，放射線量の低減に有効である。

- 放射線量の低減には, 材料の低 Co 化や皮膜処理のように 金属溶出の根本を低減する方策, 水化学制御のように溶出 した金属を燃料被覆管外面の腐食生成物への取込を抑制し て放射化を低減する方策など，複数の手段の組み合わせで， より効果的に改善できることが実証されている。

(Received February 7, 2011)

\section{文献}

1) 日本原子力学会編 ; 水化学ハンドブック (コロナ社, 2000).

2 ) ISOE Asian Technical Center ; 第17年次報告書 (2007).

3 ) J. E. Lesurf ; J. Bri. Nucl. Energy Soc., 16, 53 (1977).

4 ) D. H. Lister ; Nucl. Sci. Eng., 59, 406 (1976).

5 ) W. J. Marbble, C. J. Woodp ; Corrosion 85, paper No. 107, NACE (1985)

6 ) L. W. Niedrach, W. H. Stoddard ; Corrosion 85, paper No. 108, NACE (1985)

7 ) H. A. Levin, S. E. Garcia ; 7th Symp. Environmental Degradation Materials Nuclear Power Sys., Colorado, 1217 (1995)

8 ）日立評論；2010年1月, 40 (2010).

9 ）細川秀幸, 伊藤 剛, 長瀬 誠, 坂下元昭, 布施元正; 日本原子力 学会「2009年秋の大会」予稿集, O10, 732 (2009).

10）長瀬 誠, 碓井直志, 大内 智, 細川秀幸, 梶谷博康, 山下彰規, 南 智浩; 日本原子力学会「2009年秋の大会」予稿集, O11, 732 (2009).

11）佐藤元史, 佐藤準一; 火力原子力発電, 60, 1131 (2009).

12) K. Takeda, H. Anada, T. Nakai, T. Yokoyama ; Proc. Nuclear Plant Chemistry Conference 2010, Canada, Paper 4.10P (2010).

13) J. R. Fisher, H. L. Barnes ; J. Phys. Chem., 76, 90 (1972).

14) EPRI ; Computer-calculated potential $\mathrm{pH}$ diagram to $300{ }^{\circ} \mathrm{C}$, Vol.2, Handbook of diagram, (1983).

15）齋藤安俊, 阿竹 徹, 丸山俊夫 (編訳); 金属の高温酸化 (内田老鶴 围, 1986) 